\title{
Preparation and Characterization of Malaysian Dolomites as a Tar Cracking Catalyst in Biomass Gasification Process
}

\author{
M. A. A. Mohammed, ${ }^{1}$ A. Salmiaton, ${ }^{1}$ W. A. K. G. Wan Azlina, ${ }^{1}$ \\ M. S. Mohamad Amran, ${ }^{1}$ and Y. H. Taufiq-Yap ${ }^{2}$ \\ ${ }^{1}$ Department of Chemical \& Environmental Engineering, Faculty of Engineering, Universiti Putra Malaysia, \\ 43400 UPM Serdang, Selangor, Malaysia \\ ${ }^{2}$ Department of Chemistry, Centre of Excellence for Catalysis Science and Technology, Faculty of Science, \\ Universiti Putra Malaysia, 43400 Serdang, Selangor, Malaysia
}

Correspondence should be addressed to A. Salmiaton; mie@eng.upm.edu.my

Received 18 December 2012; Accepted 29 April 2013

Academic Editor: Johan E. Hustad

Copyright (C) 2013 M. A. A. Mohammed et al. This is an open access article distributed under the Creative Commons Attribution License, which permits unrestricted use, distribution, and reproduction in any medium, provided the original work is properly cited.

Three types of local Malaysian dolomites were characterized to investigate their suitability for use as tar-cracking catalysts in the biomass gasification process. The dolomites were calcined to examine the effect of the calcination process on dolomite's catalytic activity and properties. The modifications undergone by dolomites consequent to thermal treatment were investigated using various analytical methods. Thermogravimetric and differential thermal analyses indicated that the dolomites underwent two stages of decomposition during the calcination process. The X-ray diffraction and Fourier-transform infrared spectra analyses showed that thermal treatment of dolomite played a significant role in the disappearance of the $\mathrm{CaMg}\left(\mathrm{CO}_{3}\right)_{2}$ phase, producing the $\mathrm{MgO}-\mathrm{CaO}$ form of dolomite. The scanning electron microscopy microphotographs of dolomite indicated that the morphological properties were profoundly affected by the calcination process, which led to the formation of a highly porous surface with small spherical particles. In addition, the calcination of dolomite led to the elimination of carbon dioxide and increases in the values of the specific surface area and average pore diameter, as indicated by surface area analysis. The results showed that calcined Malaysian dolomites have great potential to be applied as tar-cracking catalysts in the biomass gasification process based on their favorable physical properties.

\section{Introduction}

Natural dolomite is the mineral form of the double carbonate of calcium and magnesium, $\mathrm{CaMg}\left(\mathrm{CO}_{3}\right)_{2}$. It occurs as the major constituent of sedimentary formations in association with calcite, $\mathrm{CaCO}_{3}$. Dolomite was first described in 1791 as a rock by the French engineer and mineralogist Deodat Gratet de Dolomieu (1750-1801) when he observed exposures in the Dolomite Alps of Northern Italy [1]. In Malaysia, dolomite is abundantly found in Perlis, the northern part of Peninsular Malaysia, and it is called "Batu Reput" by the local people. The main quarries of dolomite can be found in the surroundings of Chuping City in Perlis. Malaysian dolomite is relatively soft and easily crushed to fine powder. It has a grayish color and when crushed to form the powder, it becomes yellowish [2].
Dolomite in Malaysia is mainly used in the float glass and fertilizer industries, for soil conditioning, for use as building products in construction applications, and to prepare roads before paving with asphalt. Dolomite also has the potential to be used as a catalyst in certain chemical processes such as gasification and pyrolysis.

Gasification and pyrolysis of biomass for the production of fuel gas constitute one of the most promising processes for clean energy based on the substitution of fossil fuel with renewable energy; moreover, it decreases the global emission levels of carbon dioxide $\left(\mathrm{CO}_{2}\right)$ [3]. Tar formation is a major drawback when biomass is converted into syngas or fuel gas during the gasification process. The most common method that can effectively reduce the tar content in raw fuel gas is thermal and catalytic cracking. These methods are preferred 


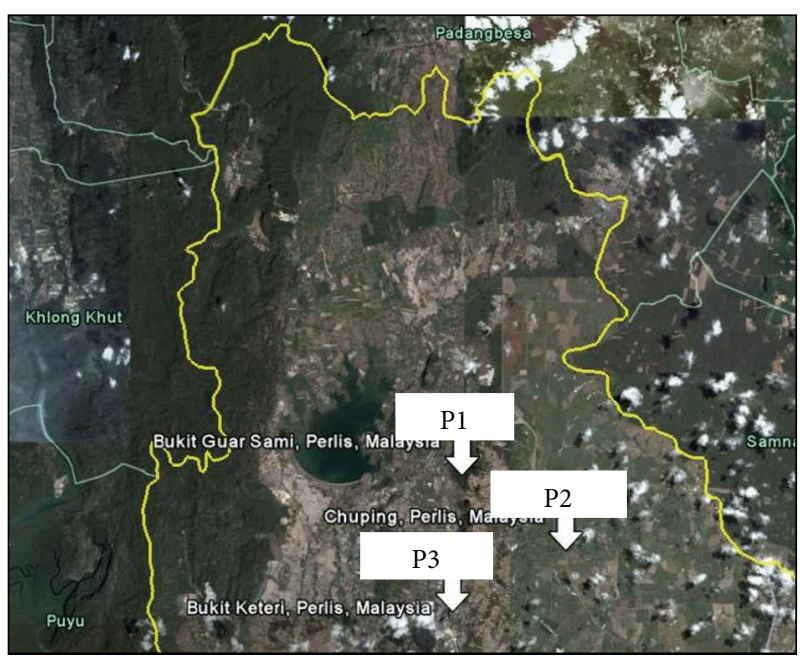

FIgUre 1: Dolomite quarries locations in Perlis State.

because the gas is maintained at a high temperature. This approach has been intensively studied for more than two decades because of its advantages including (1) conversion of tar into useful gases and (2) adjustability of the composition of the gas product. In a review of catalytic tar cracking by Sutton et al. [4], catalysts were divided into three distinct groups, namely, (1) dolomite catalysts, (2) alkali metal and other metal catalysts, and (3) nickel catalysts. Han and Kim [5] added a fourth group, that is, novel metal catalysts, which includes $\mathrm{Rh}, \mathrm{Pd}, \mathrm{Pt}$, and $\mathrm{Ru}$.

The application of dolomite as a catalyst in biomass gasification has attracted the interest of many researchers, and dolomite has been proved to have excellent tar-cracking capacity because it is cheap, easily replaceable, and can increase gas yield at the expense of the liquid products. However, the main limitations of using dolomite catalysts are their low activity levels during reforming of the methane present in the product gas and their easy erosion and breaking $[4,10]$. The chemical composition and surface area of dolomite varies with its source of supply. Several research groups $[6,8,9,11-13]$ have investigated a system of raw gas cleaning involving different types of dolomites, such as Spanish, Swedish, Finnish, and Chinese dolomites, as catalysts for tar removal.

Dolomite seems to have a significant potential to solve the problems of high tar content in producer gas and will be of significant benefit to the Malaysian economy and environment. Thus, this work was aimed at studying the suitability of Malaysian dolomite for use as a tar-cracking catalyst in the biomass gasification process. To achieve this objective, three types of local dolomites from different locations in Perlis State were prepared and characterized in terms of their properties using different analytical techniques, such as X-ray fluorescence (XRF), thermogravimetric analysis (TGA), X-ray diffraction (XRD), Fourier-transform infrared absorption spectra (FTIR), nitrogen adsorption-desorption, and scanning electron microscopy (SEM).

\section{Experimental}

2.1. Materials. Three types of natural Malaysian dolomite (P1, P2, and P3) were used and characterized in this study. Dolomite samples were obtained from dolomite quarries located in Perlis State on the northern part of Peninsular Malaysia (as illustrated in Figure 1). These samples were provided by Northern Dolomite Sdn. Bhd., Perlis; UMPAN Global Sdn. Bhd., Penang; and Kangar Dolomite Sdn. Bhd., Kedah, respectively. The original samples were in the form of stones and had to be crushed and ground until they changed to the powder form; then, they were subjected to size classification using a Retsch Test Sieve (ASTM E11, $200 \mu$ ). The dolomites were then calcined under nitrogen in a furnace at $1000^{\circ} \mathrm{C}$ for four hours. The dolomite powders with particle sizes below $0.2 \mathrm{~mm}$ for both the natural and the calcined forms were used for characterization.

\subsection{Analysis}

2.2.1. XRF Study. The chemical composition of dolomites was estimated using wavelength-dispersive XXRF (WDXRF; model BRUKER, S8 TIGER). The fused-bead technique was used to prepare the dolomite samples for XRF analysis. Specifically, $0.5 \mathrm{~g}$ of sample was mixed with $5.0 \mathrm{~g}$ of spectraflux LT-110 $\left(\mathrm{Li}_{2} \mathrm{~B}_{4} \mathrm{O}_{7}=66.5 \%, \mathrm{LiBO}_{2}=33.5 \%\right)$ and placed in a platinum crucible. The mixture was then fused at temperatures between 900 and $1250^{\circ} \mathrm{C}$ and cast in a platinum casting dish. The samples were subjected to precise control of the cooling process to ensure the reproducibility of the flat glass discs and to avoid cracking or crystallization. The samples were then placed in an XRF instrument within nine minutes for analysis.

2.2.2. Thermal Analysis. To evaluate the thermal decomposition behavior of dolomites during the calcination process, thermal analysis was carried out in a simultaneous thermogravimetric analyzer (model Mettler Toledo, TGA/SDTA851) for both TGA and differential thermal analysis (DTG). Approximately $50 \mathrm{mg}$ of dolomite powder was placed in an alumina crucible and weighed exactly. The sample was then placed inside the furnace and programmed for continuous heating from room temperature to $1000^{\circ} \mathrm{C}$ at a heating rate of $10^{\circ} \mathrm{C} / \mathrm{min}$ under nitrogen flow at the rate of $100 \mathrm{~mL} / \mathrm{min}$.

2.2.3. XRD Analysis. To examine the structural changes induced by the calcination process, the dolomite samples were characterized using a diffractometer-XRD system (model Shimadzu XRD6000), using $\mathrm{Cu}-\mathrm{K} \alpha$ (at wavelength $1.5406 \AA$ Á) radiation, fitted with a $\mathrm{Cu}$ filter on the secondary optics, and operated under $40 \mathrm{kV}$ power and $30 \mathrm{~mA}$ current. The scanning $2 \theta$ range was from $20^{\circ}$ to $90^{\circ}$, at a scan rate of $3^{\circ} / \mathrm{min}$.

2.2.4. FTIR Spectral Analysis. FTIR spectra (model PerkinElmer, 100 series) were used to confirm the structural transformation of the dolomites during the calcination process. 
TABLE 1: Analysis results of the compositions of dolomite (\%).

\begin{tabular}{lcccccccc}
\hline Compounds & $\begin{array}{c}\text { Malaysian } \\
\text { dolomite (P1) } \\
\text { This study }\end{array}$ & $\begin{array}{c}\text { Malaysian } \\
\text { dolomite (P2) } \\
\text { This study }\end{array}$ & $\begin{array}{c}\text { Malaysian } \\
\text { dolomite (P3) } \\
\text { This study }\end{array}$ & $\begin{array}{c}\text { Chinese } \\
\text { dolomite } \\
\text { (Zhejiang) } \\
{[6]}\end{array}$ & $\begin{array}{c}\text { Swedish } \\
\text { dolomite } \\
(\text { Sala) } \\
{[6]}\end{array}$ & $\begin{array}{c}\text { Indian } \\
\text { dolomite } \\
\left(\mathrm{D}_{01}\right) \\
{[7]}\end{array}$ & $\begin{array}{c}\text { Spanish } \\
\text { dolomite } \\
\text { (Malaga) } \\
{[8]}\end{array}$ & $\begin{array}{c}\text { Finnish } \\
\text { dolomite } \\
{[9]}\end{array}$ \\
\hline $\mathrm{SiO}_{2}$ & 0.07 & 0.09 & 15.37 & 1.35 & 2.21 & 0.18 & - & 2.5 \\
$\mathrm{Al}_{2} \mathrm{O}_{3}$ & 0.04 & 0.08 & 1.69 & 0.14 & 0.11 & 0.25 & 0.4 & 0.6 \\
$\mathrm{Fe}_{2} \mathrm{O}_{3}$ & 0.07 & 0.12 & 0.51 & 0.03 & 0.54 & 0.63 & 0.01 & 2.1 \\
$\mathrm{CaO}$ & 30.0 & 32.0 & 23.0 & 30.72 & 30.5 & 30.24 & 30.6 & 26.6 \\
$\mathrm{MgO}$ & 21.0 & 21.0 & 17.2 & 20.12 & 20.2 & 21.33 & 21.2 & 18.3 \\
$\mathrm{~K}_{2} \mathrm{O}$ & 0.014 & 0.026 & 0.195 & 0.02 & 0.04 & 0.03 & - & - \\
$\mathrm{Na}_{2} \mathrm{O}$ & 0.013 & 0.013 & 0.013 & 0.01 & 0.03 & 0.23 & - & - \\
$\mathrm{P}_{2} \mathrm{O}_{5}$ & 0.013 & 0.017 & 0.019 & 0.01 & 0.01 & - & - & - \\
$\mathrm{MnO}$ & 0.01 & 0.011 & 0.013 & 0.002 & - & 21.33 & - & - \\
$\mathrm{SrO}$ & 0.008 & 0.009 & 0.009 & - & - & - & - & - \\
$\mathrm{TiO}_{2}$ & 0.006 & 0.007 & 0.015 & 0.00 & 0.01 & 0.18 & - & 0.3 \\
\hline
\end{tabular}

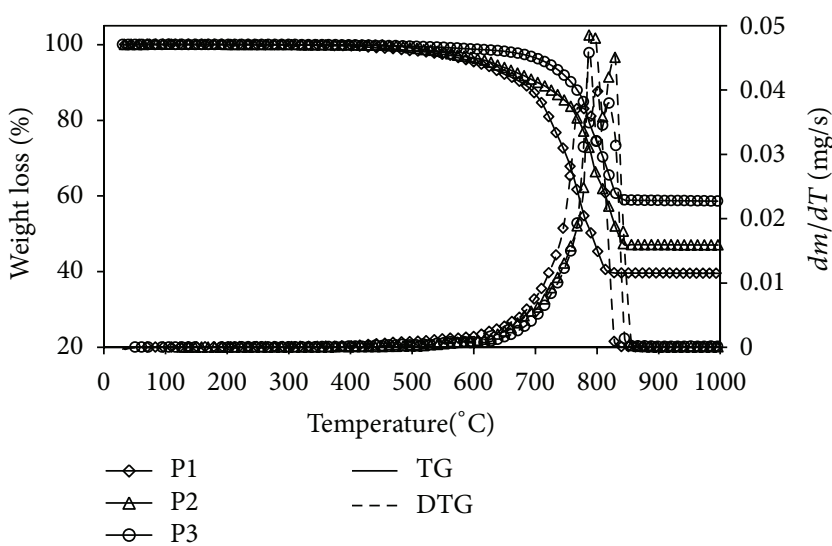

Figure 2: TG and DTG curves of Malaysian dolomites.

The spectral data were used to identify the sample compounds by matching the fingerprints of the samples with those in the database. In addition, the functional groups and structural characteristics of a compound enable us to elucidate the possible structure types. The spectrum range of the FTIR study was the mid-infrared region, which covers the frequency ranges of $500-4000 \mathrm{~cm}^{-1}$, at a resolution of $8 \mathrm{~cm}^{-1}$.

2.2.5. SEM Analysis. The surface and microstructure analysis of dolomites was carried out using an SEM instrument (model HITACHI, S-3400N). The dolomite powder was mounted onto the SEM stubs (layered with sticky carbon tape). The stub was then placed in a sputter coater (EMITECH, K550X) for five minutes for coating with gold to provide high reflectivity during the scanning process. The samples were then placed at $40^{\circ} \mathrm{C}$ in an oven before SEM analysis.

2.2.6. Physical Properties Analysis. The physical properties of the dolomites, such as specific surface area, total pore volume, and pore size distribution, were obtained by measuring their nitrogen adsorption-desorption isotherm at $77 \mathrm{~K}$ using a Quantachrome instrument (model Autosorb-1). The Brunauer-Emmet-Teller (BET) surface area was estimated from the adsorption-isotherm data using the relative pressure $\left(p / p_{o}\right)$ range of $10^{-6}$ to 1 . The total pore volume was assessed by converting the amount of nitrogen gas adsorbed at relative pressure to the volume of liquid adsorbate. The analytical method consisted of three steps, including dehydration, degassing under low vacuum pressure, and nitrogen gas adsorption at $77 \mathrm{~K}$. The resulting isotherm was analyzed using the BET adsorption method, and the pore-size distributions were derived by the Barrett-Joyner-Halenda (BJH) desorption method.

\section{Results and Discussion}

3.1. Chemical Composition of Dolomite. The chemical compositions of the various Malaysian dolomite samples, which were determined using XRF analysis, are listed in Table 1. The main contents of dolomite are $\mathrm{CaO}$ and $\mathrm{MgO}$, followed by low levels of undesirable impurities, such as $\mathrm{SiO}_{2}, \mathrm{~K}_{2} \mathrm{O}, \mathrm{Na}_{2} \mathrm{O}$, and $\mathrm{Al}_{2} \mathrm{O}_{3}$. The chemical composition of $\mathrm{P} 3$ dolomite differed significantly from that of $\mathrm{P} 1$ and $\mathrm{P} 2$. As shown in Table 1, the chemical composition analysis indicated that the $\mathrm{CaO}$ and $\mathrm{MgO}$ contents of the $\mathrm{P} 1$ and $\mathrm{P} 2$ dolomites were very close to those of other types of dolomites, whereas in the case of $\mathrm{P} 3$, these contents were relatively low. Furthermore, P1 and P2 had a much lower content of impurities than the other types of dolomites, whereas $\mathrm{P} 3$ had a higher level of impurities, especially silica $\left(\mathrm{SiO}_{2}, 15.37 \%\right)$ and alumina $\left(\mathrm{Al}_{2} \mathrm{O}_{3}, 1.69 \%\right)$. These impurities combine with $\mathrm{CaO}$ at elevated temperatures to form a slag, reducing the pore volume and the amount of available active lime [7]. Many research groups have reported that the chemical composition of dolomites play an important role when used as a catalyst for tar reforming in gasification processes [6, 8, 9, 11-13]. Myren and others reported that a mixture of silica and dolomite was not as effective as the same 


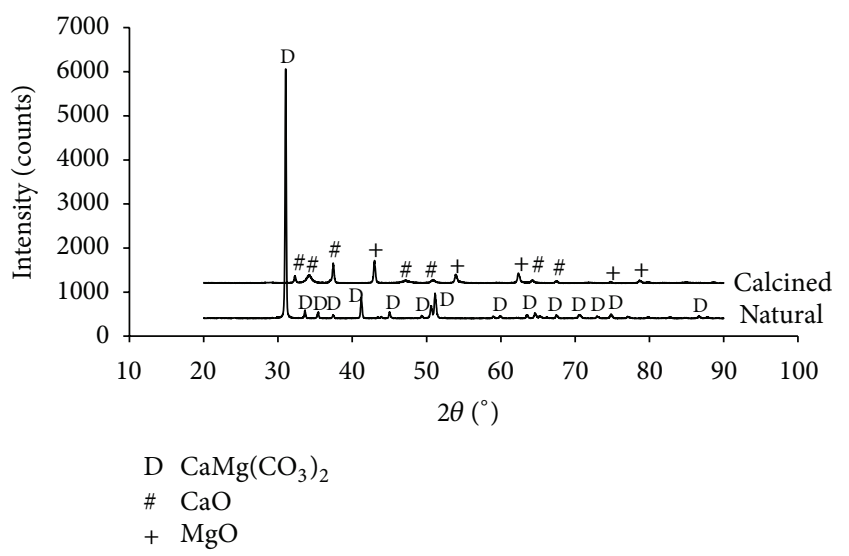

(a)

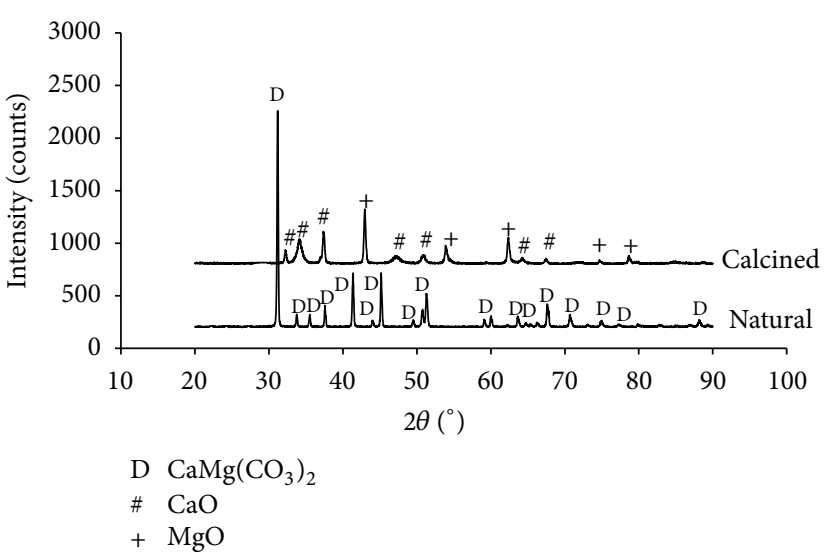

(b)

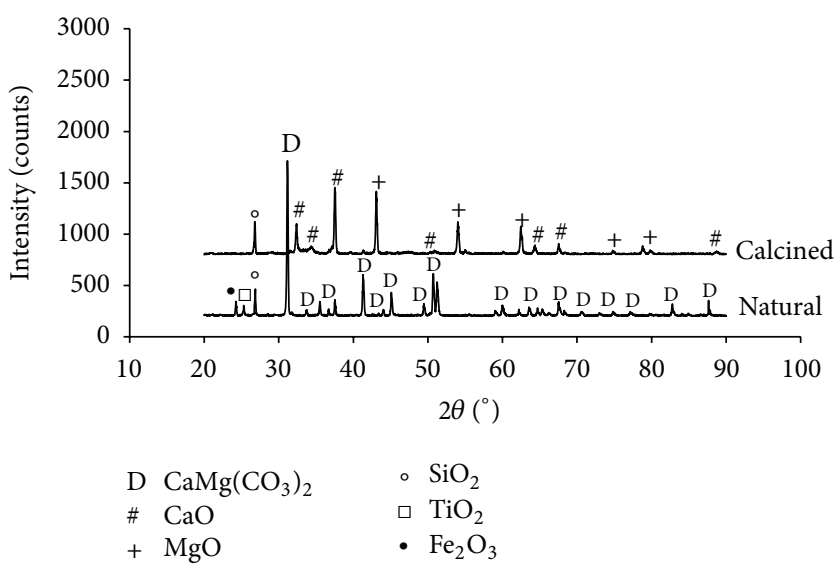

(c)

FIGURE 3: XRD analysis before and after calcination (a) P1 dolomite, (b) P2 dolomite, and (c) P3 dolomite.

amount of pure dolomite for tar cracking [14]. In general, dolomites with the lowest content of $\mathrm{CaO}$ and $\mathrm{MgO}$ show the lowest tar cracking efficiency [6].

3.2. Thermal Decomposition of Dolomite. To evaluate the thermal decomposition behavior of dolomites under calcination temperatures, thermal analysis was conducted in a simultaneous TG-DTA analyzer. The thermal decomposition characteristics of dolomites with reference to the TGA and DTG curves are displayed in Figure 2. Dolomite is the mineral form of the double carbonate of calcium and magnesium, $\mathrm{CaMg}\left(\mathrm{CO}_{3}\right)_{2}$. Under heating, dolomite is often assumed to be decomposed in two separate stages as follows $[2,15]$.

First stage:

$$
\mathrm{CaMg}\left(\mathrm{CO}_{3}\right)_{2(\mathrm{~s})} \longrightarrow \mathrm{CaCO}_{3(\mathrm{~s})}+\mathrm{MgO}_{(\mathrm{s})}+\mathrm{CO}_{2(\mathrm{~g})}
$$

Second stage:

$$
\mathrm{CaCO}_{3(\mathrm{~s})} \longrightarrow \mathrm{CaO}_{(\mathrm{s})}+\mathrm{CO}_{2(\mathrm{~g})}
$$

The first thermal decomposition stage occurs after $600^{\circ} \mathrm{C}$ and is followed by the second stage after $800^{\circ} \mathrm{C}$. From Figure 2, the observed weight loss below $600^{\circ} \mathrm{C}$ for P1, P2, and P3 was $4.59 \%, 3.42 \%$ and $1.24 \%$ respectively, whereas, the weight loss between 600 and $830^{\circ} \mathrm{C}$ was $55.77 \%, 49.26 \%$ and $39.84 \%$ respectively. The main weight loss in the $600-830^{\circ} \mathrm{C}$ range can be attributed to the decomposition of the carbonates mineral that exists in dolomite and the release of carbon dioxide as explained by (1). Therefore, the weight loss for P1 and P2 in this temperature range was higher compared to that of $\mathrm{P} 3$ due to the higher content of carbonates. In Figure 2, the DTG curves of the three types of dolomites show two peaks. For $\mathrm{P} 1$, the onset of the first peak begins at $600^{\circ} \mathrm{C}$, reaches a maximum at $767.7^{\circ} \mathrm{C}$, and ends at $790.3^{\circ} \mathrm{C}$, whereas the second peak begins at $790.3^{\circ} \mathrm{C}$, reaches a maximum at $801.3^{\circ} \mathrm{C}$, and ends at $830^{\circ} \mathrm{C}$. For $\mathrm{P} 2$, the first peak begins at $600^{\circ} \mathrm{C}$, reaches a maximum at $787.5^{\circ} \mathrm{C}$, and ends at $809.5^{\circ} \mathrm{C}$, whereas the second peak begins at $809.5^{\circ} \mathrm{C}$, reaches a maximum at $829.5^{\circ} \mathrm{C}$, and ends at $830^{\circ} \mathrm{C}$. For P3 also, the first peak begins at $600^{\circ} \mathrm{C}$, reaches a maximum at $787.5^{\circ} \mathrm{C}$, but ends at $799.3^{\circ} \mathrm{C}$, whereas the second peak begins at $799.3^{\circ} \mathrm{C}$, reaches a maximum at $819.6^{\circ} \mathrm{C}$, and ends at $830^{\circ} \mathrm{C}$. As shown in (1) and (2), the peak at the lower temperature represents the decomposition of the dolomite structure, with the release of carbon dioxide from the carbonate ion associated with the magnesium part of the structure, accompanied by the formation of calcite 


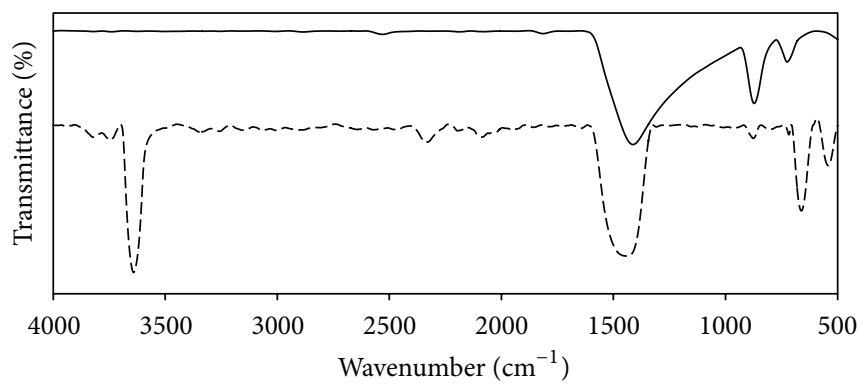

- Natural
--- Calcined

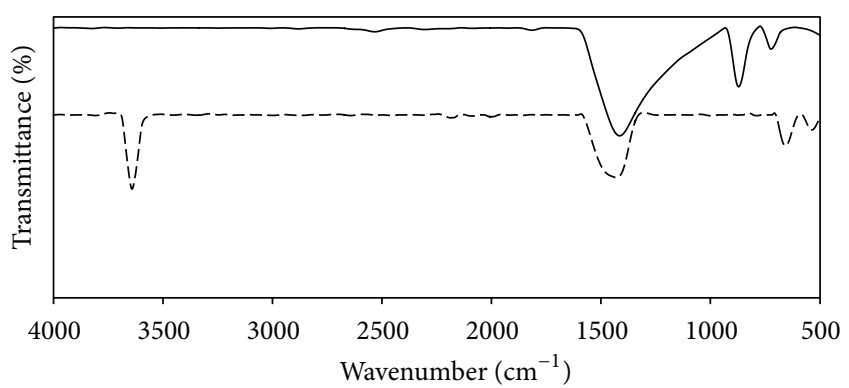

- Natural

-- Calcined

(a)

(b)

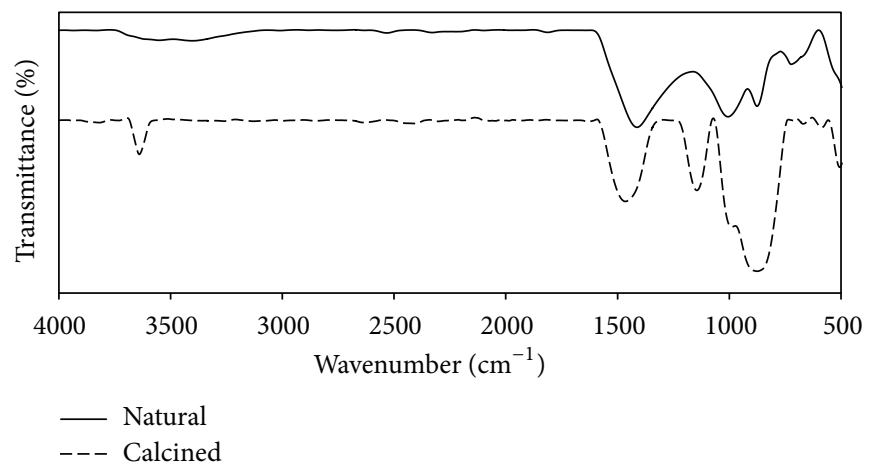

(c)

FIgURE 4: FTIR spectra before and after calcination (a) P1 dolomite, (b) P2 dolomite, and (c) P3 dolomite.

and magnesium oxide. The peak at the higher temperature corresponds to the decomposition of calcite, with the release of carbon dioxide. As shown in Figure 2, the decomposition process for P1 is initiated at lower temperatures compared to the other types of Malaysian dolomites. This probably is due to its higher content of $\mathrm{CaO}$, as presented in Table 1. These results are in agreement with the previous works by McIntosh et al. [15] and Gunasekaran and Anbalagan [7]. In addition, Farizul et al. [2] have also found that the DTG plot of Malaysian dolomite shows two peaks at 750.0 and $930.0^{\circ} \mathrm{C}$. The temperature of the second peak is higher compared to that in the present study, which can be attributed to the partial pressure of carbon dioxide in the dolomite samples, whereby the temperature of the second peak increases with increasing partial pressure of carbon dioxide. The peak temperature also depends on other procedural variables, such as the heating rate and the sample mass, because these, in turn, influence the actual atmosphere around the decomposing sample [15]. As a result, the thermal treatment process (calcination) of dolomite produced a catalyst with very high activity, due to disappearance of the $\mathrm{CaMg}\left(\mathrm{CO}_{3}\right)_{2}$ phase and producing of the $\mathrm{MgO}-\mathrm{CaO}$ form of dolomite.

3.3. XRD Analysis. The dolomites were characterized before and after calcination using XRD to analyze the effect of calcination on the dolomite structure. The results are shown in Figure 3. The XRD patterns for natural dolomites show that all peaks correspond to those of $\mathrm{CaMg}\left(\mathrm{CO}_{3}\right)_{2}$ (JCPDS
36-0426). All these peaks also have been observed in other research works $[3,7]$, indicating that the Malaysian dolomite samples have almost the same properties as the other dolomites. The XRD pattern for calcined dolomites, however, changes drastically compared to that of natural dolomites. New dominant peaks which belong to $\mathrm{CaO}$ (JCPDS 04-0777) and MgO (JCPDS 87-0652) are observed. Natural P3 sample (Figure 3(c)), on the contrary, shows three additional peaks between $2 \theta=20^{\circ}$ and $2 \theta=30^{\circ}$, which are assigned to $\mathrm{Fe}_{2} \mathrm{O}_{3}$ (JCPDS 26-1319), $\mathrm{TiO}_{2}$ (JCPDS 71-1169), and $\mathrm{SiO}_{2}$ (JCPDS 830539 ), occurring at $2 \theta=25.2^{\circ}, 26.7^{\circ}$, and $28^{\circ}$, respectively. The changes in the peaks illuminate the fact that calcination of Malaysian dolomites results in the formation of the $\mathrm{MgO}$ $\mathrm{CaO}$ form, which is the active catalytic component in tar conversion.

3.4. FTIR Spectral Analysis. The typical transmittance FTIR spectra of the Malaysian dolomites before and after the calcination process are shown in Figure 4. The FTIR spectra for all natural dolomite samples indicate that the most prevalent component present in dolomite is carbonate. The carbonate mineral group (magnesium and calcium carbonates) shows a strong and broad band near $1412 \mathrm{~cm}^{-1}$, whereas the other main components of dolomite are clearly differentiated by characteristic bands near 872 and $724 \mathrm{~cm}^{-1}$ [16]. In the case of P3 (Figure 4(c)), in addition to the band corresponding to the carbonate group, the FTIR spectra show a band at $1005 \mathrm{~cm}^{-1}$, 


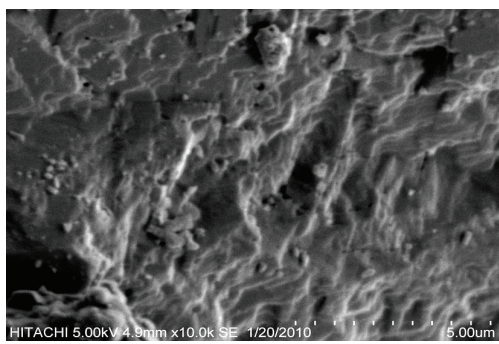

Natural P1

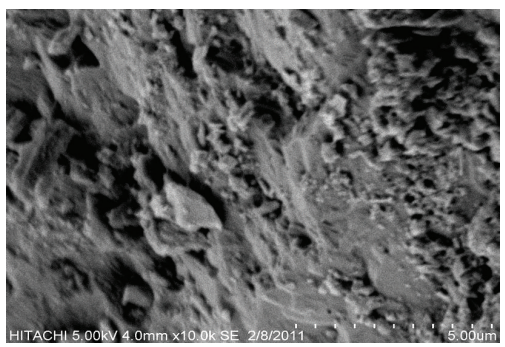

Natural P2

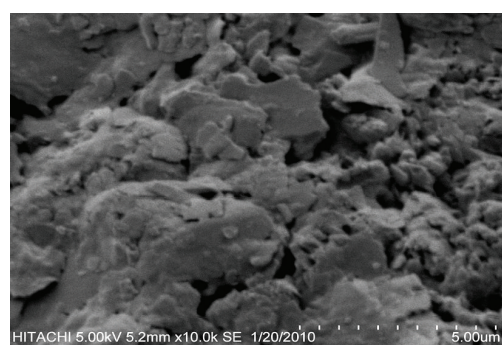

Natural P3

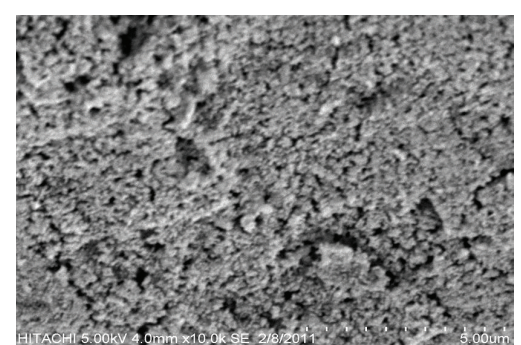

Calcined P1

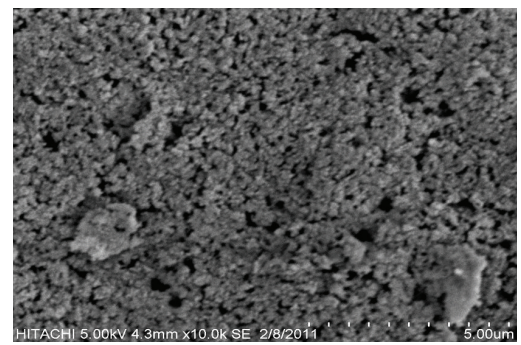

Calcined P2

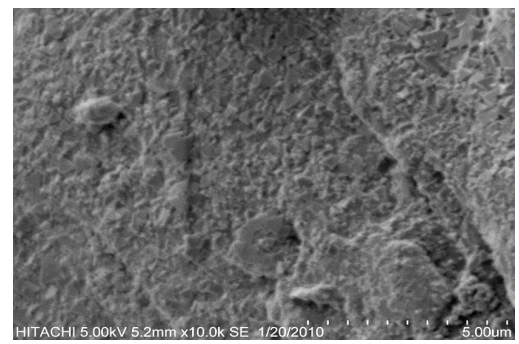

Calcined P3

FIGURE 5: SEM microphotograph of natural and calcined Malaysian dolomites.

TABLe 2: Pore characteristics of the calcined dolomites.

\begin{tabular}{lcccccc}
\hline & $\begin{array}{c}\text { P1 } \\
\text { (this study) }\end{array}$ & $\begin{array}{c}\text { P2 } \\
\text { (this study) }\end{array}$ & $\begin{array}{c}\text { P3 } \\
\text { (this study) }\end{array}$ & $\begin{array}{c}\text { Sala } \\
{[6]}\end{array}$ & $\begin{array}{c}\text { Zhejiang } \\
{[6]}\end{array}$ & $\begin{array}{c}\text { Malaga } \\
{[8]}\end{array}$ \\
\hline BET surface area $\left(\mathrm{m}^{2} / \mathrm{g}\right)$ & 15.25 & 16.85 & 6.16 & 7.3 & 5.1 & 12 \\
Pore volume $\left(\mathrm{cm}^{3} / \mathrm{g}\right)$ & 0.32 & 0.104 & 0.09 & 0.09 & 0.03 & 0.07 \\
Average pore diameter $(\AA)$ & 416 & 233 & 215 & 496 & 269 & 144 \\
\hline
\end{tabular}

referring to the presence of $\mathrm{Si}-\mathrm{O}$ vibration of the silicate phase, which is in agreement with the chemical analysis data.

The FTIR spectra for dolomites after calcination clearly show the structural transformation of natural dolomite to calcium and magnesium oxides. At this stage, the main broad band at $1412 \mathrm{~cm}^{-1}$ shifts to $1430 \mathrm{~cm}^{-1}$, and the intensity of the band decreases, showing the presence of calcium and magnesium oxides [17]. Moreover, strong and intense bands are observed at 3641 and $660 \mathrm{~cm}^{-1}$ due to calcium oxide, in addition to the band at $540 \mathrm{~cm}^{-1}$ attributable to magnesium oxide. The weak bands at 875 and $1005 \mathrm{~cm}^{-1}$ for natural P3 (Figure 4(c)) combine together to form a strong and broad band after calcination, which can be attributed to the effect of impurities such as silicates on the dolomite structure at elevated calcination temperatures. Moreover, another strong band is observed at $1144 \mathrm{~cm}^{-1}$ for calcined P3 dolomite due to the presence of silica, whereas the intensity of the calcium oxide bond at $3641 \mathrm{~cm}^{-1}$ is weak compared to the bands of the calcined samples of $\mathrm{P} 1$ and $\mathrm{P} 2$. These results are in complete agreement with the results obtained from XRD analysis.

3.5. Scanning Electron Microscopy (SEM) Analysis. As illustrated in Figure 5, the SEM micrographs of the calcined dolomites are significantly different from those of the dolomites before calcination. The SEM micrographs of natural dolomites show a rough and disordered surface with lowporosity grains, whereas the surfaces of calcined dolomites show clusters of tidy and porous grains, confirming the thermal decomposition. 


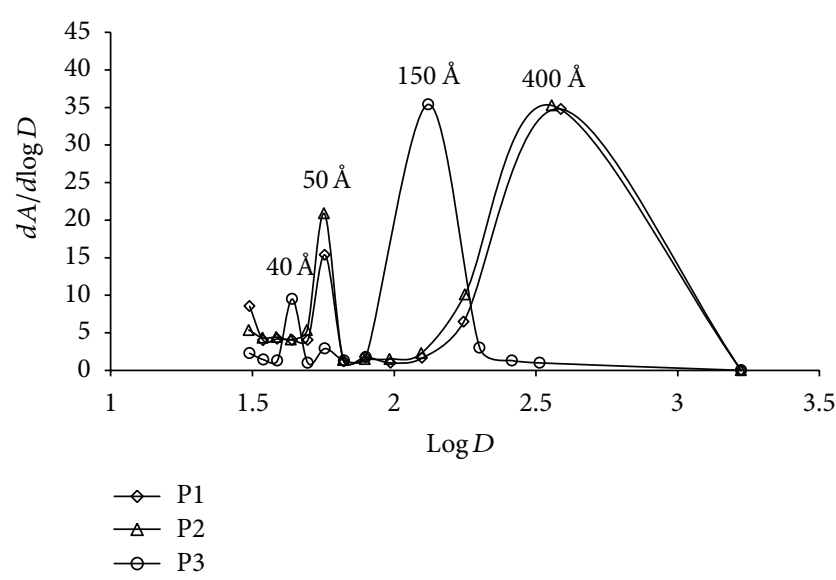

Figure 6: Pore size distribution of calcined Malaysian dolomites: $D$ : pore diameter $(\AA), A$ : BET surface area $\left(\mathrm{m}^{2} / \mathrm{g}\right)$.

3.6. Surface Area and Total Pore Volume Analysis. The BET surface area, the $\mathrm{BJH}$ pore volume, and the average pore size for calcined Malaysian dolomites are summarized in Table 2. A comparison of the surface area and pore volume (17-3000 $\AA$ ) shows that P1 and P2 dolomites have the highest surface area and pore volume compared to P3 and other published dolomites. This is possibly due to the high $\mathrm{CaO}$ and $\mathrm{MgO}$ contents in $\mathrm{P} 1$ and $\mathrm{P} 2$ dolomites and the lower contents of impurities, such as $\mathrm{SiO}_{2}, \mathrm{~K}_{2} \mathrm{O}, \mathrm{Na}_{2} \mathrm{O}$, and $\mathrm{Al}_{2} \mathrm{O}_{3}$. Slag is produced when these impurities combine with $\mathrm{CaO}$ at high temperatures, leading to a reduction in both the pore volume and the amount of available active lime [18]. The surface properties, apart from the chemical composition of dolomite, are the most important factors for selecting dolomite as the cracking catalyst in many thermochemical processes.

The pore size-distribution curves of the calcined Malaysian dolomites are shown in Figure 6. The pore-size distribution of $\mathrm{P} 1$ and $\mathrm{P} 2$ dolomites differs from that of $\mathrm{P} 3$. The pore sizes of $\mathrm{P} 1$ and $\mathrm{P} 2$ dolomites are mainly in the $400 \AA$ region, whereas the major pore size of $\mathrm{P} 3$ is in the $150 \AA$ region.

\section{Conclusions}

The natural Malaysian dolomites, after undergoing thermal treatments at high temperatures $\left(1000^{\circ} \mathrm{C}\right)$, produced activated dolomite, which could be used as a cracking catalyst in the biomass gasification process. Malaysian dolomites P1 and $\mathrm{P} 2$ contained higher amounts of $\mathrm{CaO}$ and $\mathrm{MgO}$, with lower amounts of $\mathrm{SiO}_{2}, \mathrm{~K}_{2} \mathrm{O}, \mathrm{Na}_{2} \mathrm{O}$, and $\mathrm{Al}_{2} \mathrm{O}_{3}$, compared to P3 and other dolomites (Table 1). The DTG curves showed two stages of decomposition during the calcination process. The first thermal decomposition occurred after $600^{\circ} \mathrm{C}$, followed by the second step after $800^{\circ} \mathrm{C}$. The XRD and FTIR results confirmed the structural transformation of natural dolomite to the calcium and magnesium oxide form, and the results of the BET and $\mathrm{BJH}$ analyses showed that P1 and P2 dolomites had higher surface areas and pore volumes compared to P3 and other types of dolomites. This suggests that $\mathrm{P} 1$ and $\mathrm{P} 2$ dolomites have great potential for use as tar-cracking catalysts. The most important factors that contribute to the selection of dolomites with highly efficient tar-cracking capacity are calcination balance and chemical composition in additional to geometrical surface area and average pore diameter.

\section{Acknowledgments}

The authors would like to thank Northern Dolomite Sdn. Bhd., UMPAN Global Sdn. Bhd., and Kangar Dolomite Sdn. Bhd., for their support in providing the dolomites samples. The work was financed by the Department of Chemical and Environmental Engineering, Faculty of Engineering, Universiti Putra Malaysia.

\section{References}

[1] W. L. Roberts, T. J. Cambell, and G. E. Rapp, Encyclopedia of Minerals, Van Nostrand-Reinhold, New York, NY, USA, 2nd edition, 1990.

[2] H. K. Farizul, P. C. Goh, D. M. S. N. Suhardy, H. M. D. Irfan, and S. Saiful Azhar, "Dolomite as a raw material in fertilizer production," in Proceedings of the AEESEAP International Conference, N. A. Rahim, Ed., pp. 4-8, Kuala Lumpur, Malaysia, 2005.

[3] G. Hu, S. Xu, S. Li, C. Xiao, and S. Liu, "Steam gasification of apricot stones with olivine and dolomite as downstream catalysts," Fuel Processing Technology, vol. 87, no. 5, pp. 375-382, 2006.

[4] D. Sutton, B. Kelleher, and J. R. H. Ross, "Review of literature on catalysts for biomass gasification," Fuel Processing Technology, vol. 73, no. 3, pp. 155-173, 2001.

[5] J. Han and H. Kim, "The reduction and control technology of tar during biomass gasification/pyrolysis: an overview," Renewable and Sustainable Energy Reviews, vol. 12, no. 2, pp. 397-416, 2008.

[6] Q. Z. Yu, C. Brage, T. Nordgreen, and K. Sjostrom, "Effects of Chinese dolomites on tar cracking in gasification of birch," Fuel, vol. 88, no. 10, pp. 1922-1926, 2009.

[7] S. Gunasekaran and G. Anbalagan, "Thermal decomposition of natural dolomite," Bulletin of Materials Science, vol. 30, no. 4, pp. 339-344, 2007.

[8] P. Pérez, P. M. Aznar, M. A. Caballero, J. Gil, J. A. Martín, and J. Corella, "Hot gas cleaning and upgrading with a calcined dolomite located downstream a biomass fluidized bed gasifier operating with steam-oxygen mixtures," Energy and Fuels, vol. 11, no. 6, pp. 1194-1197, 1997.

[9] P. Simell, E. Kurkela, P. Ståhlberg, and J. Hepola, "Catalytic hot gas cleaning of gasification gas," Catalysis Today, vol. 27, no. 1-2, pp. 55-62, 1996.

[10] L. Wang, C. L. Weller, D. D. Jones, and M. A. Hanna, "Contemporary issues in thermal gasification of biomass and its application to electricity and fuel production," Biomass and Bioenergy, vol. 32, no. 7, pp. 573-581, 2008.

[11] A. Orio, J. Corella, and I. Narvaez, "Performance of difference dolomites on hot raw gas cleaning from biomass gasification with air," in Proceedings of Conference on Developments in Thermochemical Biomass Conversion, pp. 1144-1150, Banff, Canada, 1996.

[12] J. Delgado, M. P. Aznar, and J. Corella, "Biomass gasification with steam in fluidized bed: effectiveness of $\mathrm{CaO}, \mathrm{MgO}$, and $\mathrm{CaO}-\mathrm{MgO}$ for hot raw gas cleaning," Industrial \& Engineering Chemistry Research, vol. 36, pp. 1535-1543, 1997. 
[13] V. Vassilatos, G. Taralas, K. Sjostrom, and E. Bjornbom, "Catalytic cracking of tar in biomass pyrolysis gas in the presence of calcined dolomite," Canadian Journal of Chemical Engineering, vol. 70, no. 5, pp. 1008-1013, 1992.

[14] C. Myren, C. Hornell, E. Bjornbom, and K. Sjoström, "Catalytic tar decomposition of biomass pyrolysis gas with a combination of dolomite and silica," Biomass and Bioenergy, vol. 23, no. 3, pp. 217-237, 2002.

[15] R. M. McIntosh, J. H. Sharp, and F. W. Wilburn, “The thermal decomposition of dolomite," Thermochimica Acta, vol. 165, no. 2, pp. 281-296, 1990.

[16] V. Ramasamy, V. Ponnusamy, S. Sabari, S. R. Anishia, and S. S. Gomathi, "Condensed matter: structural, mechanical and thermal properties," Indian Journal of Pure and Applied Physics, vol. 47, pp. 586-591, 2009.

[17] D. O. Kevin and T. A. R. R. C. Jackson, "A guide to identifying common inorganic fillers and activators using vibrational spectroscopy," Internet Journal of Vibrational Spectroscopy, vol. 2, pp. 1-11, 1998.

[18] R. K. Chan, K. S. Murthi, and D. Harrison, "Thermogravimetric analysis of Ontario limestones and dolomites I. Calcination, surface area, and porosity," Canadian Journal of Chemistry, vol. 48, no. 19, pp. 2972-2978, 1970. 


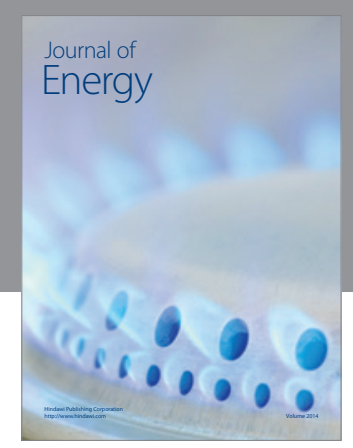

Journal of

Industrial Engineering
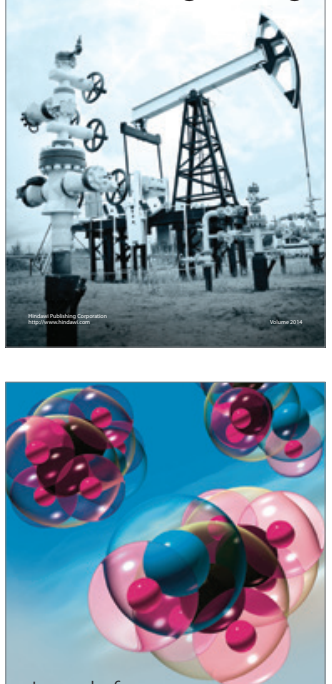

Fuels
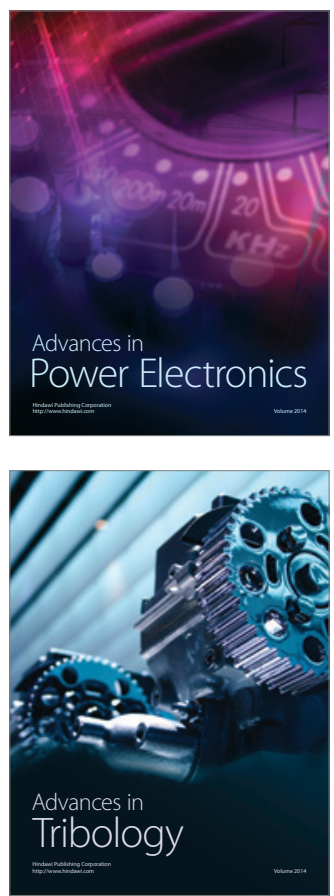

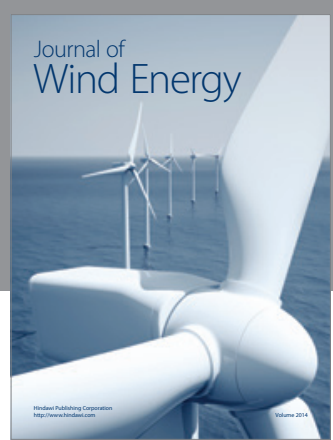

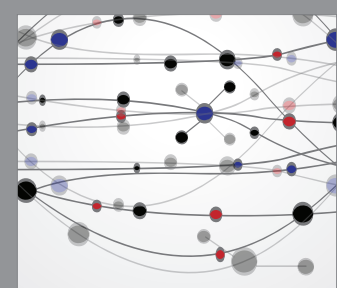

The Scientific World Journal

Submit your manuscripts at http://www.hindawi.com

Journal of

Structures
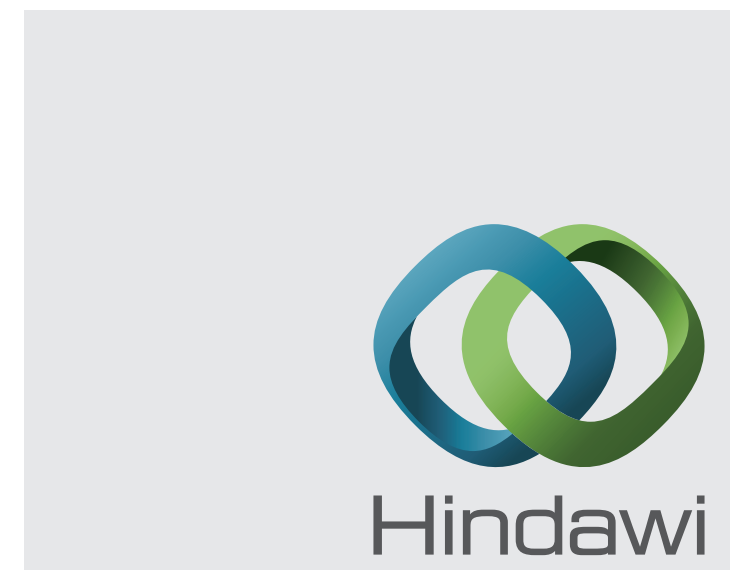

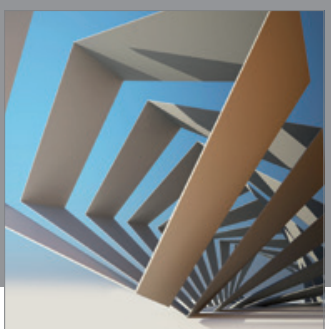

Rotating

Machinery
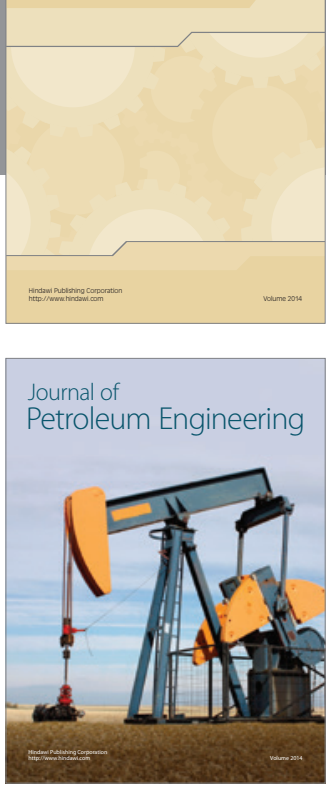

Journal of

Solar Energy
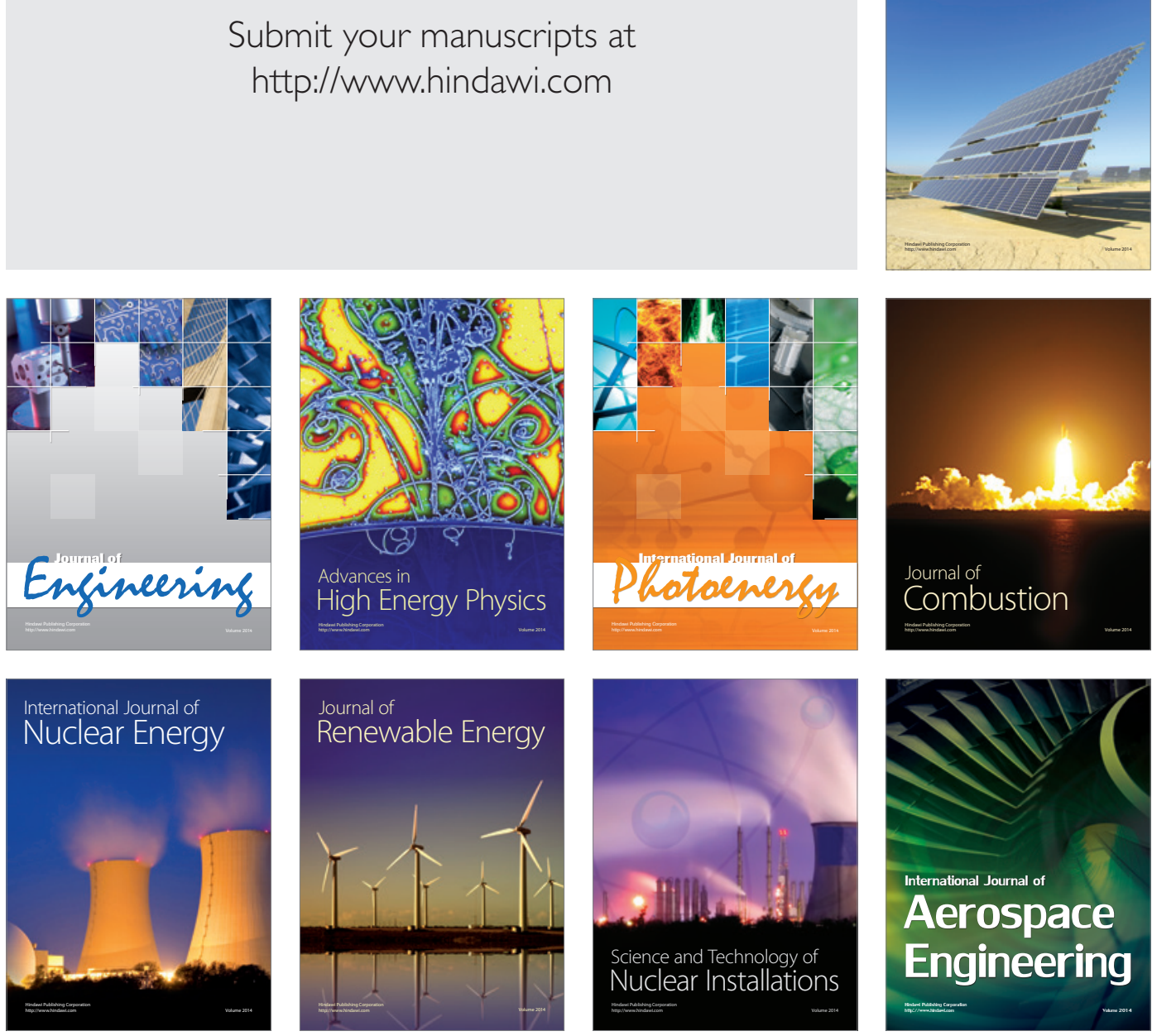